\title{
Efficacy of Fingerprint to Determine Gender and Blood Group
}

\section{Joshi $\mathrm{S}^{*}$, Garg $\mathrm{D}^{2}$, Bajaj $\mathrm{P}^{3}$ and Jindal $\mathrm{V}^{4}$}

${ }^{1}$ Post Graduate student, Department of Oral Pathology and Microbiology, Bhojia Dental College and Hospital, Bhud, Baddi, Distt Solan, H.P, India

${ }^{2}$ Reader, Department of Oral Pathology and Microbiology, Bhojia Dental College and Hospital, Bhud, Baddi, Distt Solan, H. P, India

${ }^{3}$ Professor and Head, Department of Oral Pathology and Microbiology, Bhojia Dental College and Hospital, Bhud, Baddi, Distt Solan, H.P, India

${ }^{4}$ Reader, Department of Conservative Dentistry \& Endodontics, Bhojia Dental College and Hospital, Bhud, Baddi, Distt Solan, H. P, India

*Corresponding author: Joshi S, Post Graduate student, Department of Oral Pathology and Microbiology, Bhojia Dental College and Hospital, Bhud, Baddi, Distt Solan, H.P, India, Tel: +91-9736807763, E-mail: soniajoshiop@gmail.com

Citation: Joshi S, Garg D, Bajaj P, Jindal V (2016) Efficacy of Fingerprint to Determine Gender and Blood Group. J Dent Oral Care Med 2(1): 103. doi: 10.15744/2454-3276.2.103

Received Date: October 28, 2015 Accepted Date: February 05, 2016 Published Date: February 08, 2016

\begin{abstract}
Fingerprint (dermatoglyphic) evidence is undoubtedly the most reliable and acceptable evidence till date in the court of law. Due to the immense potential of fingerprint as an effective method of identification an attempt has been made in the present work to analyze their correlation with gender and blood group of an individual. A total of 100 dental students randomly chosen belonging to the age group 18- 25 year of Bhojia Dental College \& Hospital, Baddi (HP) were included in the study. The fingerprints were taken of all ten fingers \& Pattern was observed. Results show that Loops were the most common (53.4\%) fingerprint pattern while whorls were moderate (31.2\%) and arches were the least common (15.1\%). Males had a higher incidence of whorls and females had a higher incidence of loops. Frequency of loops was highest in both the Rh-positive and Rh-negative subjects of ABO blood groups; followed by whorls and arches. Incidence of loops were highest in $\mathrm{Rh}+\mathrm{ve}$ females and incidence of whorls were highest in $\mathrm{Rh}+$ males except in $\mathrm{o}-\mathrm{ve}$ cases in which arches are significantly higher in females compare to males and whorls are highest in males. There is an association between distribution of fingerprint patterns, blood group and gender and thus prediction of gender and blood group of a person is possible based on his fingerprint pattern.
\end{abstract}

Keywords: Arch; Blood Groups; Fingerprint

\section{Introduction}

The skin covers the anterior surface of human hand and planter surface of the human foot is different in the texture and appearance than the one which covers the rest of the human body. This skin on the palmer and planter surface is continuously wrinkled with narrow minute ridges known as friction ridges [1].

A friction ridge is a raised portion of the epidermis on the digits or on the palmer and plantar skin, consisting of one or more connected ridge units of friction ridge skin [2,3]. A finger print is an impression of the friction ridges on all parts. The dermal carvings or finger prints appear for the first time on the human fingers, palm, soles and toes from $12^{\text {th }}$ to $16^{\text {th }}$ week of embryonic development and their formation gets completed by the $14^{\text {th }}$ week i.e. about the $6^{\text {th }}$ fetal month. The ridges thus, formed during the fetal period do not change their course or alignment throughout the life of an individual, until destroyed by decomposition of the skin after death [4].

Two person having identical fingerprint is about one in 64 thousand millions. A reliable personal identification is critical in the subject of forensics as is faced with many situations like civil, criminal, commercial and latest in financial transaction frauds, where the question of identification becomes a matter of paramount importance [5]. Fingerprint may be deposited in natural secretions from the eccrine glands present in friction ridge skin or they may be made by ink or other contaminants transferred from the peaks of friction skin ridges to a relatively smooth surface $[6,3]$.

Dermatoglyphics is study of pattern of fine ridges on fingers, palms and soles. The term dermatoglyphics was coined by Cummins [7]. The term coined by Cummins and Mildo (1943). It includes anthropologic, genetic and Egypt logic study of finger prints [8]. 
Fingerprint is a multifactor trait. Large number of genes plays their role along with environmental influence. Monozygotic twins have close resemblance in dermatoglyphic pattern showing common genetic factors and least differences showing influences of other factors. Actually there is large number of genes determining the ridge pattern. Chromosomal aberrations affect these genes and produce variations in dermatoglyphic pattern in various chromosomal syndromes. There are three basic dermatoglyphic patterns; whorl, loop and arch. Whorl pattern has two deltas, Loop has one delta and Arch has one central or no delta at all. Loop pattern is further classified into Radial and Ulnar loop depending on the side to which loop opens [9].

The ABO blood groups were discovered by Karl Landsteiner in 1901. Blood group system was discovered way back in 1901 by Karl Landsteiner. Total 19 major groups have been identified which vary in their frequency of distribution amongst various races of mankind. Clinically, only 'ABO' and 'Rhesus' groups are of major importance. 'ABO' system is further classified as A, B, AB, O blood group types according to presence of corresponding antigen in plasma. 'Rhesus' system is classified into ' $\mathrm{Rh}+\mathrm{ve}$ ' and 'Rh ve' according to the presence or absence of 'D' antigen [10]. Further studies on the ABO blood group system, by the other workers, suggested that the blood groups were inherited. But, the exact manner of inheritance of the ABO blood group was revealed by Bernstein (1924) [11].

The human beings have been using fingerprint as a means of identification for a long time but in this study we have made an effort to take a step further to "study a relationship between pattern of fingerprint, gender and ABO blood group", so that one can get an idea about the expected blood group and gender from the study of fingerprint pattern and vice versa.

\section{Materials and Methods}

After obtaining clearance from institutional ethics committee, this prospective study was carried out among dental students of Bhojia Dental College \& Hospital, Baddi, Himachal Pradesh. Total 100 students ( 50 male \& 50 female) belonging to the age group 18- 25 voluntarily participated in the study.

Each subject was asked to wash his / her hands thoroughly with soap and water and dry them using a towel. Then they were asked to press their fingertip on the stamp pad (CAMLIN Company of size $157 \times 96 \mathrm{~mm}$ ) and then to the paper to transfer the fingerprint impression. The same method was repeated for all the fingers of both hands. In this way, the plain fingerprints of all the ten digits were taken separately on the same sheet of paper (Figure 1). After the fingerprints were acquired, Primary patterns (loops, whorl and arches) were observed with the help of a powerful hand lens (TAG3 ${ }^{\text {ma }}$ magnifying glass $50 \mathrm{Mm}$ double reading glass optical graded lens with 5x and 10x magnifying capacity). Each finger in the finger print slip was assigned a number, ex: The 1st number was given to the right thumb and 10th number to left little, based on the appearance of ridge lines according to Henry's system of classification, (Henry's Ten Digit Classification, 1900) [12]. The purpose of classifying the finger prints is to get them systematically back whenever necessary. The blood group was identified using antiserum A, B and D (Figure 2).

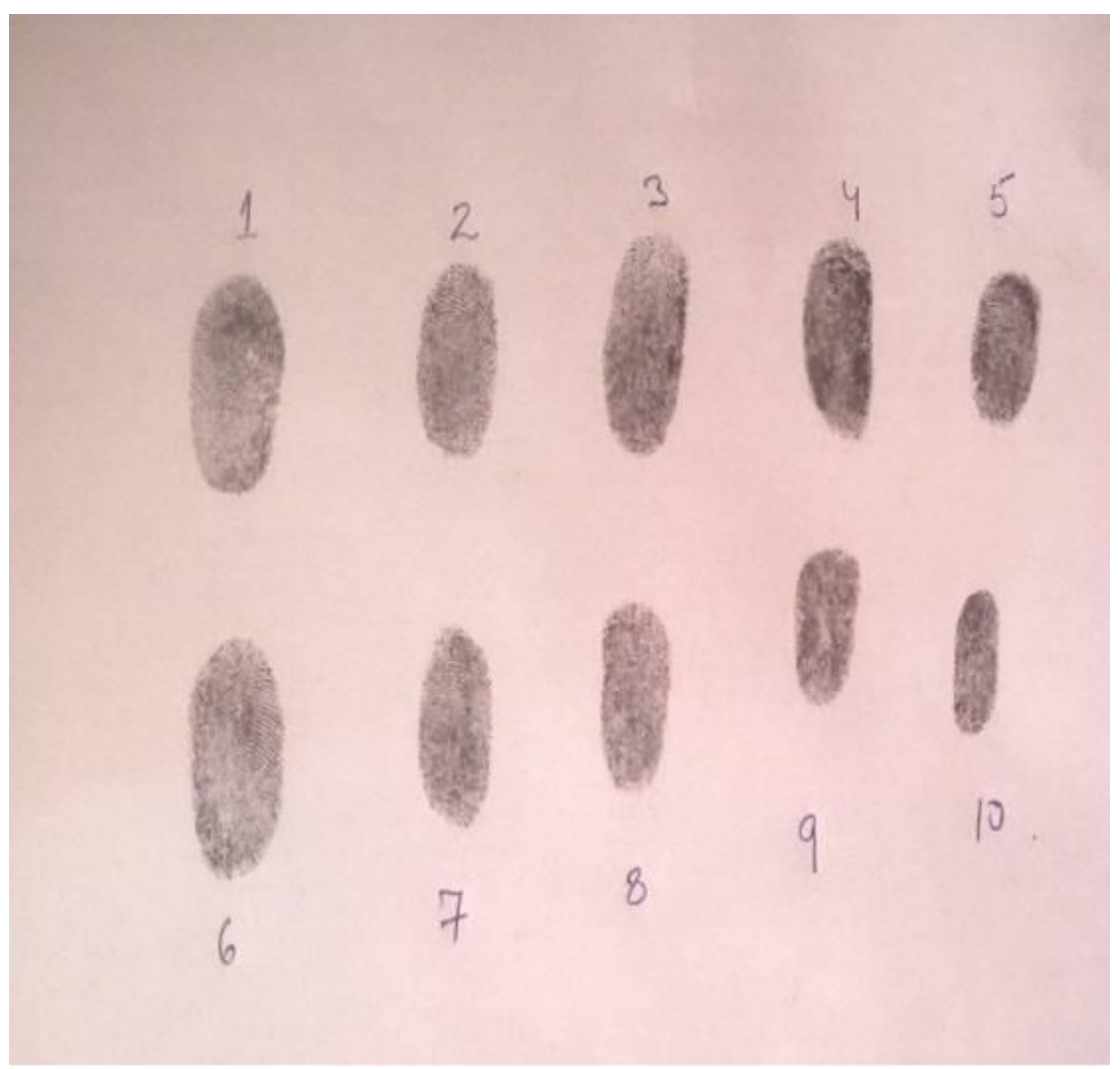

Figure 1: Fingerprints in 10 digits 


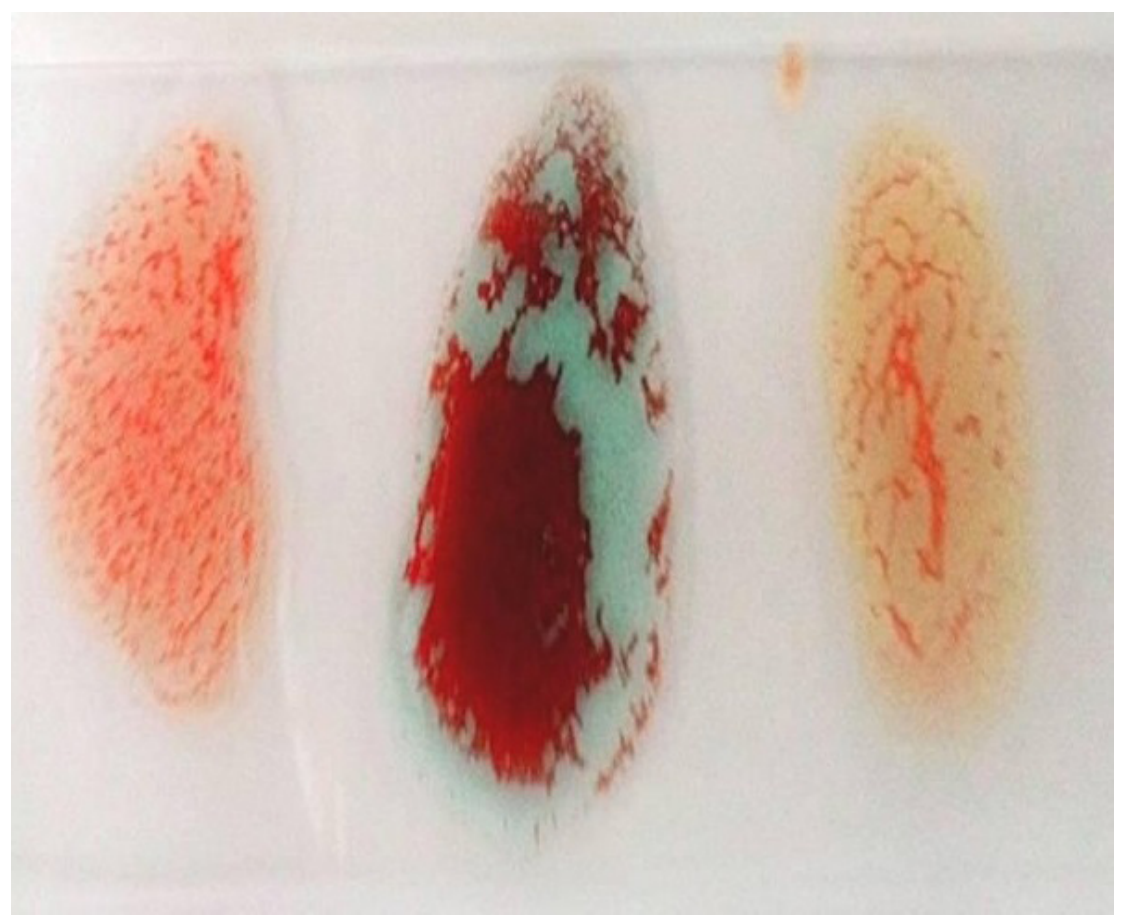

Figure 2: Identification of blood group using antiserum A, B and D

The distribution of dermatoglyphic fingertip patterns in both hands of individuals and its relationship with gender and different $\mathrm{ABO}$ and $\mathrm{Rh}$ blood groups were evaluated and analysed statistically. Chi square $\left(\chi^{2}\right)$ test was used to compare variables and tests were considered significant when $\mathrm{P}$ value $<0.05$.

\section{Exclusion Criteria}

Students with permanent scars on their fingers or thumbs, with any hand deformities due to injury, birth defect or disease, those having worn finger-prints, extra, webbed or bandaged fingers, were excluded from the study.

\section{Results}

Table 1 shows distribution of blood groups according to Gender. Majority of the subjects belonged to the blood group B i.e. $41(41 \%)$ followed by $\mathrm{O} ; 27(27 \%), \mathrm{A} ; 16(16 \%)$ and AB; 11 (11\%). Blood group B was predominantly found in females but in males both $\mathrm{B}$ and $\mathrm{O}$ were almost equal.

\begin{tabular}{|c|c|c|c|c|}
\hline S.No. & Blood Group & Male & Female & Total \\
\hline 1 & $\mathrm{AB}+$ & 8 & 3 & 11 \\
\hline 2 & $\mathrm{~A}+$ & 5 & 11 & 16 \\
\hline 3 & $\mathrm{~A}-$ & 1 & 2 & 3 \\
\hline 4 & O+ & 17 & 10 & 27 \\
\hline 5 & $\mathrm{~B}+$ & 18 & 23 & 41 \\
\hline 6 & O- & 1 & 1 & 2 \\
\hline \multicolumn{2}{|c|}{ Total } & 50 & 50 & 100 \\
\hline
\end{tabular}

Table 1: Distribution of blood groups according to Gender

Table 2 shows distribution of Pattern of Finger-prints among Males and Females.

Loops were the most common pattern, registering 53.4\% frequency in the study; followed by whorls (31.2\%) and arches (15.1\%). Frequency of loops was found to be higher in females $(53.3 \%)$ than in males (46.6\%) whereas whorls were more frequent in males (54.2\%) as compared to females (44.7\%). $39.1 \%$ of arches were present in males and $60.1 \%$ in females.

\begin{tabular}{|c|c|c|}
\hline Types & Male & Female \\
\hline LOOPS & $249(24.9 \%)$ & $285(28.5 \%)$ \\
\hline WHORLS & $171(17.1 \%)$ & $144(14.4 \%)$ \\
\hline ARCHES & $59(5.9 \%)$ & $92(9.2 \%)$ \\
\hline
\end{tabular}


Table 3 shows Pattern of Finger Prints in Different Blood Groups among males and females

Frequency of loops was highest in both the Rh-positive and Rh- negative subjects of ABO blood groups; followed by whorls and arches. Incidence of loops were highest in $\mathrm{Rh}+\mathrm{ve}$ females and incidence of whorls were highest in $\mathrm{Rh}+$ males except in $\mathrm{o}-\mathrm{ve}$ cases in which arches are significantly higher in females compare to males and whorls are highest in males.

\begin{tabular}{|c|c|c|c|c|c|c|}
\hline Blood Group & Fingerprint & Male & Female & Chi Square & P-Value & \\
\hline $\mathrm{AB}+$ & $\begin{array}{l}\text { Loop } \\
\text { Whorl } \\
\text { Arch }\end{array}$ & $\begin{array}{l}31 \\
36 \\
12 \\
\end{array}$ & $\begin{array}{c}22 \\
2 \\
6\end{array}$ & 10.45 & $\begin{array}{l}0.0012 \\
0.0002 \\
0.5676\end{array}$ & $\begin{array}{l}\text { HS } \\
\text { HS } \\
\text { NS }\end{array}$ \\
\hline \multirow[b]{2}{*}{$A+$} & Fingerprint & Male & Female & & & \\
\hline & $\begin{array}{l}\text { Loop } \\
\text { Whorl } \\
\text { Arch }\end{array}$ & $\begin{array}{c}31 \\
10 \\
9\end{array}$ & $\begin{array}{l}59 \\
31 \\
20\end{array}$ & $\begin{array}{l}0.98 \\
1.21\end{array}$ & $\begin{array}{c}0.322 \\
0.2713 \\
1\end{array}$ & $\begin{array}{l}\text { NS } \\
\text { NS } \\
\text { NS }\end{array}$ \\
\hline \multirow[b]{2}{*}{ A- } & Fingerprint & Male & Female & & & \\
\hline & $\begin{array}{l}\text { Loop } \\
\text { Whorl } \\
\text { Arch }\end{array}$ & $\begin{array}{l}3 \\
6 \\
1\end{array}$ & $\begin{array}{c}12 \\
6 \\
3\end{array}$ & & $\begin{array}{c}0.2451 \\
0.2353 \\
1\end{array}$ & $\begin{array}{l}\text { NS } \\
\text { NS } \\
\text { NS }\end{array}$ \\
\hline \multirow[b]{2}{*}{$\mathrm{O}+$} & Fingerprint & Male & Female & & & \\
\hline & $\begin{array}{l}\text { Loop } \\
\text { Whorl } \\
\text { Arch }\end{array}$ & $\begin{array}{l}98 \\
48 \\
24\end{array}$ & $\begin{array}{l}47 \\
33 \\
19\end{array}$ & $\begin{array}{l}2.87 \\
0.68 \\
1.12\end{array}$ & $\begin{array}{l}0.0902 \\
0.4096 \\
0.2899\end{array}$ & $\begin{array}{l}\text { NS } \\
\text { NS } \\
\text { NS }\end{array}$ \\
\hline \multirow[b]{2}{*}{ B+ } & Fingerprint & Male & Female & & & \\
\hline & $\begin{array}{l}\text { Loop } \\
\text { Whorl } \\
\text { Arch }\end{array}$ & $\begin{array}{c}115 \\
52 \\
13\end{array}$ & $\begin{array}{c}130 \\
72 \\
29\end{array}$ & $\begin{array}{l}2.28 \\
0.28 \\
3.19\end{array}$ & $\begin{array}{c}0.1311 \\
0.5967 \\
0.074\end{array}$ & $\begin{array}{l}\text { NS } \\
\text { NS } \\
\text { NS }\end{array}$ \\
\hline \multirow[b]{2}{*}{ O- } & Fingerprint & Male & Female & & & \\
\hline & $\begin{array}{l}\text { Loop } \\
\text { Whorl } \\
\text { Arch }\end{array}$ & $\begin{array}{l}2 \\
8 \\
0\end{array}$ & $\begin{array}{l}5 \\
0 \\
5\end{array}$ & & $\begin{array}{c}0.1311 \\
0.5967 \\
0.074\end{array}$ & $\begin{array}{c}\text { NS } \\
\text { HS } \\
\text { S }\end{array}$ \\
\hline
\end{tabular}

Table 3: Pattern of Finger Prints in Different Blood Groups among Males and Females

\section{Discussion}

Many criteria were used for the purpose of identification like race, sex, age, complexion, hair, scar, tattoo, footprint and occupation marks but fingerprint is found to be the most reliable. A reliable personal identification is critical in the subject of forensics as is faced with many situations like civil, criminal, commercial and latest in financial transaction frauds, where the question of identification becomes a matter of paramount importance. Although human beings have been using fingerprints as a means of identification for a long time but in this study we have made an effort to take step further to "study a relationship between pattern of fingerprint, gender and ABO blood group", so that one can get an idea about the expected blood group and gender from the study of fingerprint pattern and vice versa [5].

The present study reveals that there was an association between distribution of fingerprint (dermatoglyphic) pattern, Gender \& blood groups. The general distribution pattern of the primary finger print was of the same order in individuals with $\mathrm{ABO}$; $\mathrm{Rh}$ blood groups i.e. high frequency of loops, moderate of whorls and low of arches. The same findings were observed by Kshirsagar, et al., Mahajan, et al. and Bharadwaja, et al. [13-15].

Majority of the subjects in our study belonged to blood group B; followed by blood group O, A and AB. Majority of subjects (96\%) were $\mathrm{Rh}$ positive while only $4 \%$ were $\mathrm{Rh}$ negative. The general distribution pattern of the primary fingerprint was of the same order in individuals with $\mathrm{A}, \mathrm{B}, \mathrm{AB}$ and $\mathrm{O}$ blood groups i.e high frequency of loops, moderate of whorls and low of arches. This is in accordance with the study conducted by Bharadwaja, et al. [15]. Similar findings were seen in Rh-positive and Rh-negative individuals except in blood group $\mathrm{O}$ negative where whorls predominated.

Blood group AB had more of whorls in males and loops in females in our study which is in accordance with the study conducted by Bharadwaja, et al. [6]. Present study also revealed that whorls were more common in females. The present study also reveals that frequency of loops is greater in females as compared to a higher frequency of whorls in males. Arches were found to be more frequent in females, similar results seen in study conducted by Rastoogi [3].

The findings of the study can be concluded as the Loops are the most commonly occurring finger-print pattern and Arches are the least common, Blood group $\mathrm{O}$ positive is the most common and A negative is the rares, Loops are predominant in blood group $\mathrm{A}, \mathrm{B}, \mathrm{AB}$ and $\mathrm{O}$ in both $\mathrm{Rh}$ positive and $\mathrm{Rh}$ negative individuals except in $\mathrm{O}$ negative where whorls are more common and Males have a higher incidence of whorls and females have a higher incidence of loops. 


\section{Conclusion}

This study is an attempt made by us to associate finger prints with gender and blood group of an individual and hence we conclude that prediction of blood group and gender to some extent may be possible with the study of finger print pattern which may in turn enhance the authenticity of the fingerprints in identification and detection of criminals.

\section{References}

1. Surinder Nath (1984) Finger Print Identification. Gita Press Delhi 1-15.

2. Vij K (2005) Textbook of Forensic Medicine and Toxicology, $3^{\text {rd }}$ ed New Delhi Elsevier 89-91.

3. Rastogi P, Pillai KR (2005) A study of fingerprints in relation to gender and blood group. J Indian Acad Forensic Med 32: 11-4.

4. Bhavana D, Ruchi J, Prakash T, Kalyan JL (2013) Study of Fingerprint Patterns in Relationship with Blood group and Gendera Statistical Review. Res J Forensic Sci 1: 15-7.

5. Raloti SK, Shah KA, Patel VC, Menat AK, Moril RN, et al. (2013) An Effort To Determine Blood Group And Gender From Pattern Of Finger Prints. Nat J Com Med 4: 158-60.

6. Pillay VV (2009) Textbook of Forensic Medicine and Toxicology. 15 ${ }^{\text {th }}$ ed. Paras Medical Publishers Hyderabad 53-94.

7. Cummins H, Midlo C (1926) Palmar and plantar epidermal ridge configuration (Dermatoglyphics) in Europeans and Americans. Am J Phy Anthrop 179: 741802

8. Umraniya YN, Modi HH, Prajapati HK (2013) Study of Correlation of Finger Print Patterns in Different ABO, Rh Blood Groups. Int J Sci Res 2: 337-9.

9. Hirsch W (1978) Dermatoglyphics and Creases in Their Relationship to Clinical syndromes: A Diagnostic Criterion in Dermatoglyphics, An International Perspective by Jamshed Mavalwala, Moulton Publishers, The Hague/Paris 263-82.

10. Bijlani RL Textbook of Physiology, $2^{\text {nd }}$ ed. Blood Groups: 93-4.

11. Harmening DM, Deborch F (1994) 'Modern blood banking and transfusion practices.' $3^{\text {rd }}$ Ed. Jaypee, New Delhi.

12. Henry ER (1900) Classification and Uses of Fingerprints. London: Routledge.

13. Kshirsagar SV, Burgul SN, Kamkhedkar SG (2003) Study of fingerprint patterns in ABO blood group. J Anat Soc India 52: 82-115.

14. Mahajan AA (1986) Dermatoglyphics and ABO blood group. Thesis submitted for MS Anatomy, Aurangabad.

15. Bharadwaja A, Saraswat PK, Aggarwal SK, Banerji P, Bharadwaja S, et al. (2004) Pattern of fingerprints in different ABO blood groups. JIAFM $26: 6$.

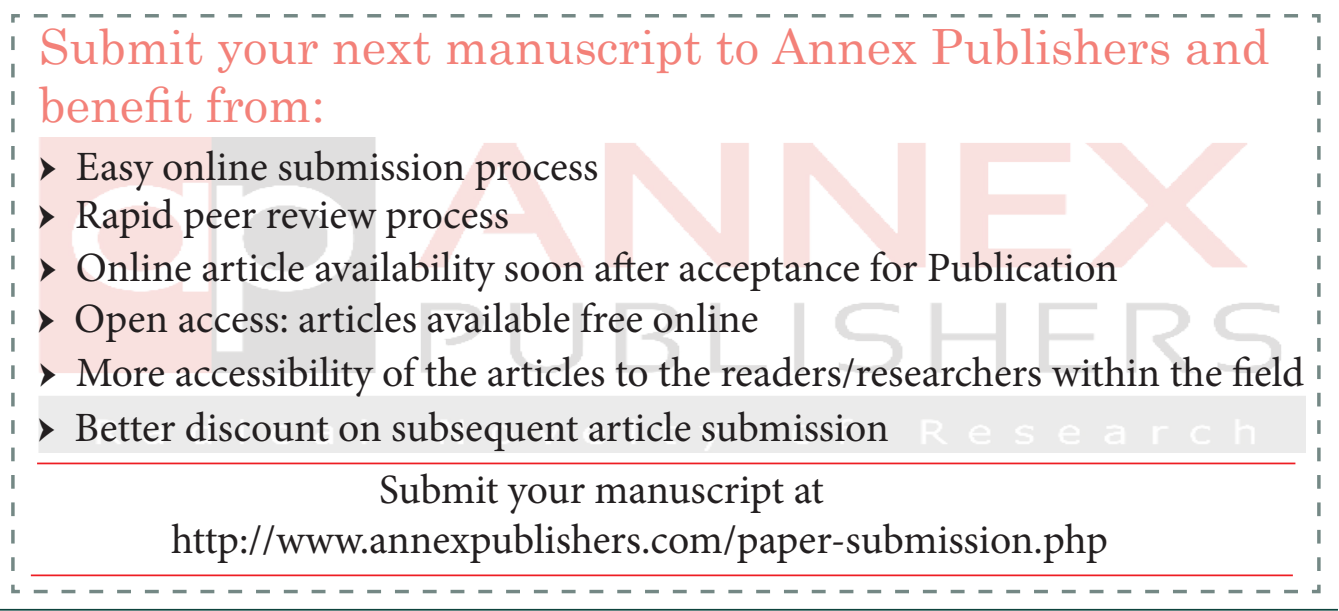

